\begin{tabular}{ll}
\hline ISSN: 1410-8917 & Jurnal Kimia Sains dan Aplikasi 23 (6) (2020): 196-202 \\
Jurnal Kimia & Jurnal Kimia Sains dan Aplikasi \\
Aplikasi & Journal of Scientific and Applied Chemistry \\
\hline
\end{tabular}

\title{
The Use of Silica Extracted from Kaolin as Catalyst Support for Esterification of 4-Hydroxybenzoic Acid with Sucrose
}

\author{
Iman Abdullah $^{\text {a, }}{ }^{,}$, Widayanti Wibowo ${ }^{\text {a }}$, Soleh Kosela ${ }^{a}$, Yuni K. Krisnandi ${ }^{a}$ \\ ${ }^{a}$ Department of Chemistry, FMIPA Universitas Indonesia, Kampus UI Depok, Depok 16424, Indonesia \\ * Corresponding author: iman.abdullah@sci.ui.ac.id \\ https://doi.org/10.14710/jksa.23.6.196-202
}

\section{Article Info}

Article history:

Received: $13^{\text {th }}$ January 2020

Revised: $14^{\text {th }}$ May 2020

Accepted: $21^{\text {st }}$ May 2020

Online: $30^{\text {th }}$ June 2020

Keywords:

silica; kaolin; solid support; acid catalyst; esterification

\begin{abstract}
$\mathrm{SiO}_{2}$ was extracted from kaolin using concentrated $\mathrm{HCl}$ and $\mathrm{HNO}_{3}$ mixture and used as solid support for both Bronsted $\left(\mathrm{HClO}_{4}\right.$ and $\left.\mathrm{H}_{2} \mathrm{SO}_{4}\right)$ and Lewis Acid $\left(\mathrm{AlCl}_{3}\right.$ and $\mathrm{ZnCl}_{2}$ ). Before extraction, kaolin was calcined at $800^{\circ} \mathrm{C}$ for eight hours to form metastable kaolin. After the extraction procedure, silica was recovered in $51.6 \%$ yield. Silica and the resulting solid acids were then characterized using XRD, XRF, and FTIR. XRD pattern shows that silica synthesized from kaolin is in the mixture of amorphous and $\alpha$-quartz silica. Immobilization of acids alters its structure becomes more crystalline. XRF analysis shows that the loading of $\mathrm{AlCl}_{3}$ and $\mathrm{ZnCl}_{2}$ was 9.5 and $24.8 \%$, respectively. The acid catalysts were then used in the esterification reaction of 4-hydroxybenzoic acid with sucrose. The reactions were conducted in dimethyl sulfoxide (DMSO) solvent by varying reaction time and reaction temperature. The highest conversion of starting materials and selectivity towards ester was obtained over the $\mathrm{AlCl}_{3} / \mathrm{SiO}_{2}$ catalyst. DPPH radical scavenging test shows that the ester exhibits good antioxidant activity.
\end{abstract}

\section{Introduction}

Silica is a solid inorganic material with several unique characteristics, such as high surface area, high thermal stability, high absorption capacity, and ease of reactivation [1]. Therefore, silica is often used for various purposes such as adsorbent [1, 2, 3], catalyst or catalyst support $[4,5,6]$, a hard template in the synthesis of porous materials $[7,8]$, and biomedical applications [9, 10]. One of the synthesis methods of silica is through extraction from aluminosilicate minerals such as kaolin [11] and bentonite [12]. Compared to the synthesis from silica precursors such as tetraethyl orthosilicate (TEOS), this method has some advantages, especially in terms of local natural resource utilization, which could reduce the synthesis cost and the dependency from an expensive precursor. Moreover, aluminosilicate mineral such as kaolin is an abundant mineral in Indonesia [13] and has high silica content, about $50 \%$ by weight [11].

Due to its acidity, silica is often used as an acid catalyst or catalyst support in some acid-catalyzed type reactions such as in esterification reaction [14]. In this case, Bronsted or Lewis Acid is immobilized on the silica surface to increase its acidity. The resulting acid heterogeneous catalyst could then be used in the reaction. There are many reports on the utilization of heterogeneous acid catalyst in esterification reaction, such as Amberlit-IR120 [15], zeolite [16], zirconia [17], montmorillonite [17, 18], titanosilicate [19], heteropoly acids/carbon [20] or several mesoporous silicas synthesized from TEOS [21]. However, the utilization of silica, particularly extracted from kaolin as catalyst support for esterification reaction, remains unexplored. Therefore, herein we report our research on this issue. Esterification reaction between 4-hydroxybenzoic acid, a phenolic compound, and sucrose was selected as the reaction model since this reaction could produce an antioxidant, a substance with the ability to quench free radical. Previously, Farhoosh et al. [22] reported the antioxidative properties of some 4-hydroxybenzoic acid derivatives in the form of its ester, which are influenced by their structure. A recent study by Shim et al. [23] revealed that 4-hydroxybenzoic acid $\beta$-d-glucosyl ester extracted from Pyracantha angustifolia shows good antioxidant activity based on DPPH radical-scavenging test. 


\section{Methodology}

\subsection{Materials}

All materials were used as received without any further purification. Kaolin was purchased from Bratachem; whereas $\mathrm{HCl}(37 \%), \mathrm{HNO}_{3}(70 \%)$, sucrose, 4hydroxybenzoic acid (99\%), dimethyl sulfoxide (99.9\%), $\mathrm{AlCl}_{3}(99 \%), \mathrm{ZnCl}_{2}$ (98\%), $\mathrm{HClO}_{4}(70 \%), \mathrm{H}_{2} \mathrm{SO}_{4}(95-98 \%)$ were obtained from Sigma Aldrich.

\subsection{Experiment}

\subsubsection{Extraction of Silica from Kaolin}

Silica was extracted from kaolin according to the procedure reported by Bakri et al. [11]. Kaolin was calcined at $800^{\circ} \mathrm{C}$ for 6 hours to produce metastable kaolin. Then $15 \mathrm{~mL}$ of water, $280 \mathrm{~mL}$ of concentrated $\mathrm{HCl}$, and $94 \mathrm{~mL}$ of concentrated $\mathrm{HNO}_{3}$ (aqua regia) were added to $40.0 \mathrm{~g}$ of metastable kaolin. The mixture was stirred under reflux at $100^{\circ} \mathrm{C}$ for 8 hours in an air atmosphere condition. The resulting silica was filtered off, washed with acid-free distilled water, and dried in an oven at $110^{\circ} \mathrm{C}$ overnight.

\subsubsection{Preparation of Silica Gel}

A $30 \mathrm{~g}$ of extracted $\mathrm{SiO}_{2}$ and $69 \mathrm{~g}$ of $\mathrm{K}_{2} \mathrm{CO}_{3}$ was mixed and crushed, and the mixture was melted in a furnace at $800^{\circ} \mathrm{C}$ for 3 hours. The resulting silicate was settled overnight and then soaked in $400 \mathrm{~mL}$ distilled water for 12 hours. The remaining precipitate was removed by paper filtration and washed with distilled water. A solution of $6.0 \mathrm{M} \mathrm{HNO}_{3}$ was then added dropwise under stirring to the filtrate. Then it allowed standing for two nights at room temperature for the polymerization of silicic acid to silica hydrogel. The gel was filtered off and washed, then dried in an oven at $110^{\circ} \mathrm{C}$ overnight.

\subsubsection{Acid Immobilization.}

Immobilization of Bronsted Acids on silica gel was conducted according to the method reported by Chakraborti et al. [14] with some modifications. A $5 \mathrm{~g}$ of silica gel was dispersed in $10 \mathrm{~mL}$ of ether. Then $0.3676 \mathrm{~g}$ of concentrated $\mathrm{HClO}_{4}(68 \%)$ was added, and the mixture was stirred for 30 minutes at room temperature. The solvent was then evaporated by air-drying, and the residue was dried at $110^{\circ} \mathrm{C}$ for 5 hours. The immobilization of $\mathrm{H}_{2} \mathrm{SO}_{4}$ was conducted using the same procedure to get acid loading of $5 \%(\mathrm{w} / \mathrm{w})$. Whereas immobilization of Lewis Acids $\left(\mathrm{AlCl}_{3}\right.$ and $\mathrm{ZnCl}_{2}$ ) was conducted via wet impregnation method, adopting the procedure reported by Bakri et al. [11]. A $3 \mathrm{~g}$ of silica gel was dispersed into $30 \mathrm{~mL}$ of $1 \mathrm{M} \mathrm{AlCl}_{3}$ (or $\mathrm{ZnCl}_{2}$ ) solution and stirred for 2 hours. Then the mixture was allowed to stand for 24 hours. The mixture was filtered, and the precipitate was dried in an oven at $110^{\circ} \mathrm{C}$. The immobilization procedure was performed once for each acid, following the references as mentioned earlier.

\subsubsection{Esterification reaction of 4-hydroxybenzoic acid with sucrose.}

Esterification reactions were carried out by mixing $0.1380 \mathrm{~g}$ (1 mmole) 4-hydroxybenzoic acid, $1.0260 \mathrm{~g}$ (3 mmoles) sucrose, $10 \mathrm{~mL}$ dimethyl sulfoxide (DMSO), and
$0.0400 \mathrm{~g}$ catalyst into a round bottom flask reactor equipped with condenser and thermometer. The mixture was heated while stirring on a hotplate stirrer using a reflux system under an air atmosphere condition. The reactions were conducted by varying reaction temperatures $\left(80,100\right.$, and $\left.120^{\circ} \mathrm{C}\right)$ and reaction times $(0.5,1,2,4,8$, and $24 \mathrm{~h})$.

\subsubsection{HPLC Analysis.}

Separation and identification of products were performed with the HPLC instrument. The column used was a $\mathrm{C}_{18}$ reversed-phase with a flow rate of $0.8 \mathrm{~mL} / \mathrm{min}$, column temperature of $40^{\circ} \mathrm{C}$ and injection volume of $20 \mu \mathrm{L}$. The gradient elution system was used according to the method proposed by Barbas et al. [24] for separating the parabens.

\subsubsection{Antioxidant activity}

The resulting product's antioxidant activity was determined using the $\mathrm{DPPH} \cdot$ scavenging method [25, 26, 27]. A total of $2 \mathrm{~mL}$ of $0.2 \mathrm{mM}$ DPPH solution was mixed in a vial with a $2 \mathrm{~mL}$ sample by varying sample concentrations from 10 to $75 \mathrm{ppm}$. The absorbance of the mixtures was measured at $515 \mathrm{~nm}$ every 5 minutes for a total of 30 minutes. The absorbance measurements were conducted once for each concentration to determine the product's inhibition concentration $\left(\mathrm{IC}_{50}\right)$. The same procedure was used to evaluate the $\mathrm{IC}_{50}$ of ascorbic acid and 4-hydroxybenzoic acid as a comparison.

\section{Results and Discussion}

The extraction of silica from kaolin was conducted by using aqua regia. Prior to extraction, kaolin was calcined at $800^{\circ} \mathrm{C}$ for eight hours to form metastable kaolin. During this process, the dihydroxylation reaction occurred, causing a decrease in kaolin crystal volume and the Si-O-Al bond's strength. Thus, this thermal process facilitates the extraction of silica since the SiO-Al bond could be easily cleaved upon stirring in $\mathrm{HCl}-\mathrm{HNO}_{3}$ media. After the extraction procedure, silica was recovered in a $64.8 \%$ yield. To increase the surface area and pore volume, silica was further converted to silica gel [28]. Silica was reacted with carbonate to produce silicate, then polymerized in acidic conditions to produce the gel. The reactions are shown in Figure 1. After these processes, silica gel was recovered in $51.6 \%$.

$$
\begin{aligned}
& \underset{\text { silica }}{\mathrm{SiO}_{2}(\mathrm{~s})}+\mathrm{K}_{2} \mathrm{CO}_{3}(\mathrm{~s}) \underset{800{ }^{\circ} \mathrm{C}}{\longrightarrow} \mathrm{K}_{2} \mathrm{SiO}_{3}(\mathrm{~s})+\mathrm{CO}_{2}(\mathrm{~g}) \\
& \mathrm{K}_{2} \mathrm{SiO}_{3}(\mathrm{~s}) \stackrel{\mathrm{H}_{2} \mathrm{O}(\mathrm{l})}{\longrightarrow} 2 \mathrm{~K}^{+}(\mathrm{aq})+\mathrm{SiO}_{3}{ }^{2-}(\mathrm{aq})
\end{aligned}
$$

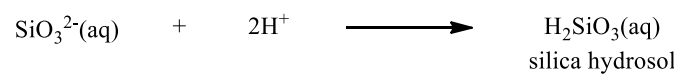

$$
\begin{aligned}
& \mathrm{H}_{2} \mathrm{SiO}_{3}(\mathrm{aq}) \stackrel{\text { polymerized }}{\longrightarrow} \stackrel{\text { dried }}{\longrightarrow} \mathrm{SiO}_{2} \times \mathrm{xH}_{2} \mathrm{O} \\
& \text { silica hydrosol silica gel }
\end{aligned}
$$

Figure 1. Reaction equations in the conversion of silica to silica gel 


\subsection{Catalysts Characterization}

XRD data in Figure 2 shows that the silica gel synthesized from kaolin is in the mixture of amorphous and $\alpha$-quartz silica. This is supported by the lack of sharpness (peaks) of the resulting diffraction pattern. Compared to the ICDD data, the structure of the synthesized silica gel is close to amorphous $\mathrm{SiO}_{2}$ with the ID number of 82-1572 and $\alpha$-quartz $\mathrm{SiO}_{2}$ (ID 83-2187).

The synthesized silica gel was further used as catalyst support of $\mathrm{HClO}_{4}$ and $\mathrm{H}_{2} \mathrm{SO}_{4}$ via acid immobilization method. The diffraction patterns of silica, kaolin, and the resulting $\mathrm{HClO}_{4} / \mathrm{SiO}_{2}$ and $\mathrm{H}_{2} \mathrm{SO}_{4} / \mathrm{SiO}_{2}$ catalysts are shown in Figure 2. Based on XRD data, the diffraction patterns of the catalysts differ from that of silica gel, especially in the case of the $\mathrm{H}_{2} \mathrm{SO}_{4} / \mathrm{SiO}_{2}$ catalyst. Sharp diffraction peaks appear at $2 \theta=23.5^{\circ}$, $29.6^{\circ}, 33.9^{\circ}, 41.3^{\circ}$, and $46.8^{\circ}$. This suggests that the immobilization of acid alter the structure of silica gel becomes more crystalline.

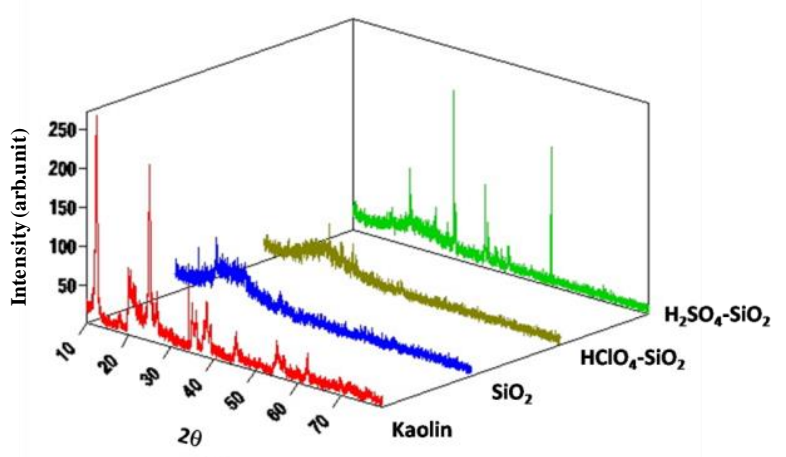

Figure 2. Comparison of diffraction patterns of kaolin, $\mathrm{SiO}_{2}$ (silica gel), $\mathrm{HClO}_{4} / \mathrm{SiO}_{2}, \mathrm{H}_{2} \mathrm{SO}_{4} / \mathrm{SiO}_{2}$

FTIR spectra of the support and catalysts are shown in Figure 3. In the spectra of silica, there is a wide band in the region between $3500-2800 \mathrm{~cm}^{-1}$. This is a typical hydrogen bond of the - $\mathrm{OH}$ group in a solid sample, which indicates strong hydrogen bonds, while the band at $1063 \mathrm{~cm}^{-1}$ shows the asymmetric vibration of $\mathrm{Si}-\mathrm{O}-\mathrm{Si}$ [29]. The band of $\mathrm{Si}-\mathrm{O}-\mathrm{Si}$ is also observed in the spectra of the $\mathrm{HClO}_{4} / \mathrm{SiO}_{2}$ and $\mathrm{H}_{2} \mathrm{SO}_{4} / \mathrm{SiO}_{2}$ but shifted to a slightly longer wavenumber due to bond effect of the immobilized acid. In $\mathrm{HClO}_{4} / \mathrm{SiO}_{2}$, the band shifted to $1092 \mathrm{~cm}^{-1}$, whereas in the $\mathrm{H}_{2} \mathrm{SO}_{4} / \mathrm{SiO}_{2}$, it was shifted to $1096 \mathrm{~cm}^{-1}$. In the spectra of $\mathrm{H}_{2} \mathrm{SO}_{4} / \mathrm{SiO}_{2}$, there is also a sharp peak at $1383.95 \mathrm{~cm}^{-1}$, which related to the asymmetric vibrations of $\mathrm{O}=\mathrm{S}=\mathrm{O}$ from the sulfate group. Whereas in $\mathrm{HClO}_{4} / \mathrm{SiO}_{2}$ spectra, there is a typical peak at $630 \mathrm{~cm}^{-1}$, indicating the presence of $\mathrm{HClO}_{4}$ in silica gel. The existence of this peak is also following what has been reported by Yang and Tang [30] regarding $\mathrm{HClO}_{4}$ incorporation in nanoporous silica gels.

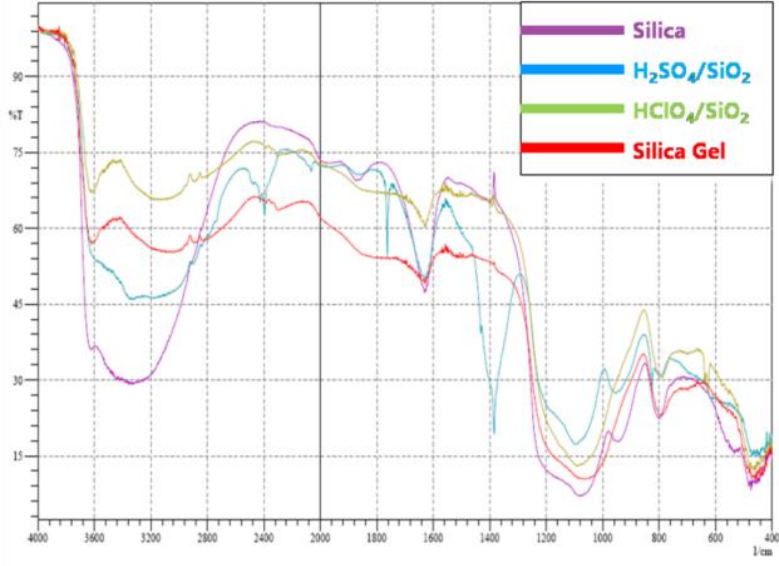

Figure 3. Combined FTIR spectra of silica, silica gel, $\mathrm{HClO}_{4} / \mathrm{SiO}_{2}$, and $\mathrm{H}_{2} \mathrm{SO}_{4} / \mathrm{SiO}_{2}$ catalyst

Apart from being used as solid support for Bronsted Acids, the synthesized silica gel was also used as catalyst support for Lewis Acids, namely $\mathrm{AlCl}_{3}$ and $\mathrm{ZnCl}_{2}$, via wet impregnation method. XRF analysis shows that the immobilization of Lewis Acids gave $\mathrm{AlCl}_{3}$ and $\mathrm{ZnCl}_{2}$ with acid loading of 9.5 and $24.8 \%$, respectively, as shown in Table 1.

Table 1. Elemental analysis data of $\mathrm{ZnCl}_{2} / \mathrm{SiO}_{2}$ and $\mathrm{AlCl}_{3} / \mathrm{SiO}_{2}$ catalyst

\begin{tabular}{cccc}
\hline \multicolumn{2}{c}{$\mathrm{ZnCl}_{2} / \mathrm{SiO}_{2}$} & \multicolumn{2}{c}{$\mathrm{AlCl}_{3} / \mathrm{SiO}_{2}$} \\
\hline element & \%weight & element & \%weight \\
\hline $\mathrm{Si}$ & 52.5648 & $\mathrm{Si}$ & 66.7275 \\
$\mathrm{Zn}$ & 24.8326 & $\mathrm{Al}$ & 9.5398 \\
$\mathrm{Cl}$ & 19.1464 & $\mathrm{Cl}$ & 17.1359 \\
$\mathrm{~K}$ & 1.8198 & $\mathrm{~K}$ & 4.3508
\end{tabular}

\subsection{Esterification Reaction}

Esterification of sucrose with 4-hydroxybenzoic acid produced pale yellow to brownish-yellow product mixture, as shown in Figure 4, depending on reaction conditions such as catalyst, time, and temperature. The longer the reaction time and the higher the reaction temperature tend to produce a darker colored reaction mixture. This indicates that more reactants were converted, and products were formed.

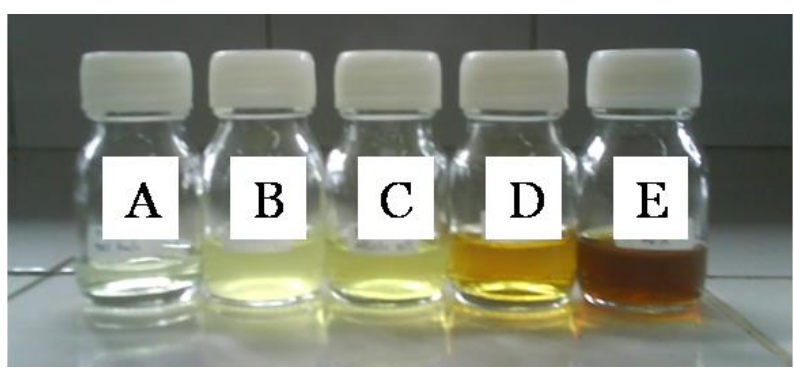

Figure 4. Typical appearance of the reaction mixtures obtained over the $\mathrm{HClO}_{4} / \mathrm{SiO}_{2}$ catalyst. (A) $80^{\circ} \mathrm{C}, 2 \mathrm{~h}$; (B) $80^{\circ} \mathrm{C}, 4 \mathrm{~h}$; (C) $80^{\circ} \mathrm{C}, 8 \mathrm{~h}$; (D) $100^{\circ} \mathrm{C}, 8 \mathrm{~h}$; (E) $120^{\circ} \mathrm{C}, 8 \mathrm{~h}$.

HPLC analysis of all samples shows the same tendency, i.e., the retention time of 4-hydroxybenzoic acid is higher than that of the forming esters. A typical 
chromatogram of the sample is shown in Figure 5. In the chromatograph, 4-hydroxybenzoic acid has a retention time of 10.6 minutes while the esters have a retention time ranging from 4 to 6 minutes, which is shorter than that of the starting material. This suggests that the ester has higher polarity than 4-hydroxybenzoic acid due to the presence of several unreacted $-\mathrm{OH}$ groups from sucrose/glucose part of the ester. HPLC and MS data in Figure 6 suggest that the monoester dominates the products. This is related to the peak with $\mathrm{m} / \mathrm{z}$ at 299 $\mathrm{g} / \mathrm{mol}$, representing the monoester of glucose/fructose.

\subsubsection{Effect of acid type catalysts}

Four catalysts gave almost the same conversion of 4-hydroxybenzoic acid $(\sim 70 \%)$, as shown in Figure 7 , whereas selectivity of catalysts toward the formation of monoester varies from $87 \%$ for $\mathrm{HClO}_{4} / \mathrm{SiO}_{2}$ to $92 \%$ for $\mathrm{AlCl}_{3} / \mathrm{SiO}_{2}$. This highly selective but average in conversion might be caused by the fact that the catalyst is lack of macroporosity character. The average pore diameter of the $\mathrm{HClO}_{4} / \mathrm{SiO}_{2}$ catalyst is only around $25 \AA$ (classified as mesoporous material according to IUPAC nomenclature), with the surface area of $125 \mathrm{~m}^{2} / \mathrm{g}$ (Table 2). This could restrict the formation of di-, tri- or polyester of 4-hydroxybenzoate due to the size effect of those esters. Other catalysts could have similar textural properties since the support used was the same as that of the $\mathrm{HClO}_{4} / \mathrm{SiO}_{2}$ catalyst.

Table 2. Textural properties of $\mathrm{HClO}_{4} / \mathrm{SiO}_{2}$

\begin{tabular}{cc}
\hline Parameter & Value \\
\hline Surface area $\left(\mathrm{m}^{2} / \mathrm{g}\right)$ & 125.01 \\
Average of pore diameter $(\AA)$ & 25.734 \\
Total of pore volume $(\mathrm{cc} / \mathrm{g})$ & 0.08043
\end{tabular}

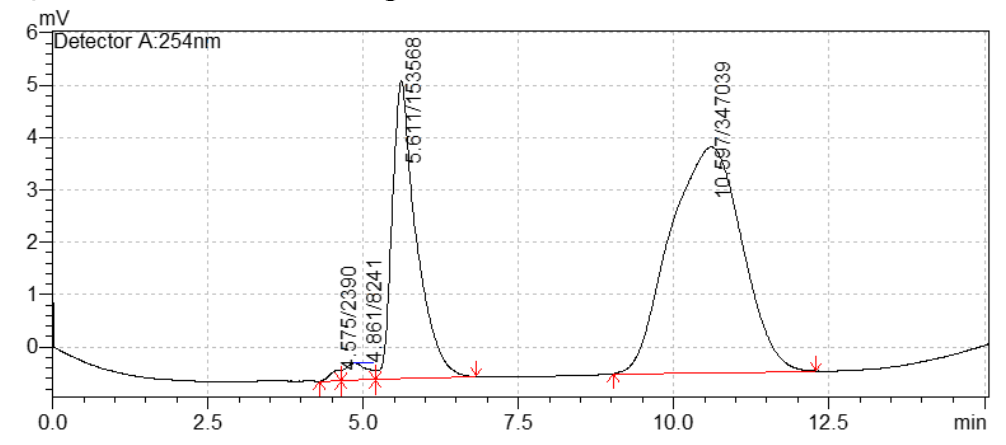

Figure 5. Typical chromatograph of the reaction mixture (reaction conditions: $1 \%$ of $\mathrm{H}_{2} \mathrm{SO}_{4} / \mathrm{SiO}_{2}$ catalyst, $100^{\circ} \mathrm{C}$ for 4 hours)

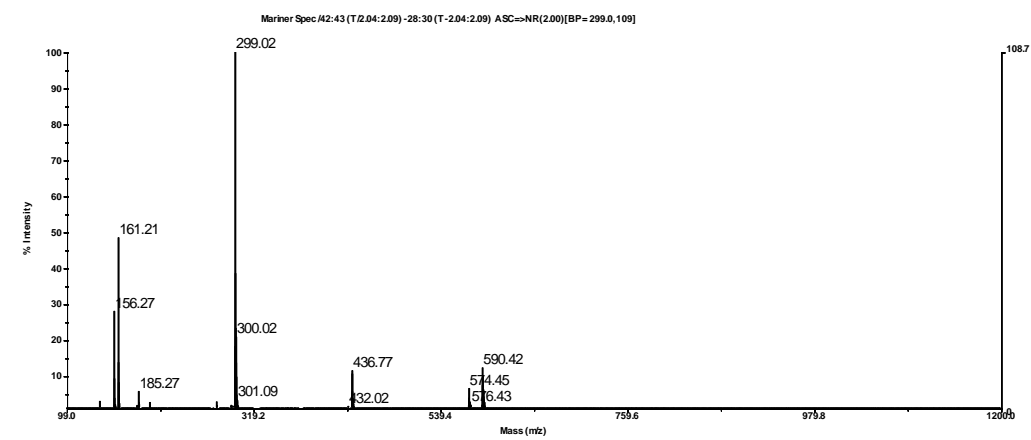

Figure 6. LC-MS of the ester

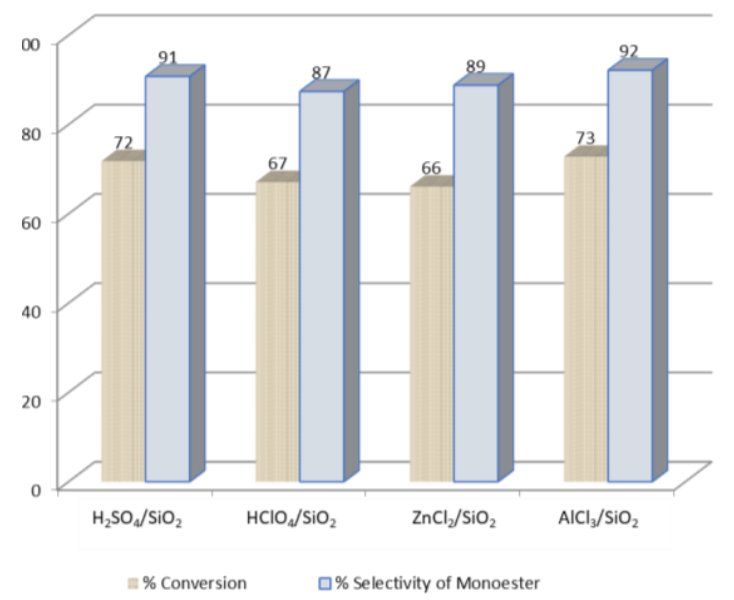

Figure 7. Activity and selectivity of various catalysts (reactions were carried out at $100^{\circ} \mathrm{C}$ for eight hours for all catalysts) 


\subsubsection{Effect of Reaction Time and Temperature}

The higher percent of conversion was obtained in a longer reaction time since more reactants interact with each other, including the catalyst to form an ester. However, as shown in Figure 8(a), the reaction reaches equilibrium after 2 hours. This is due to the maximum catalyst activity, which is related to its lack of macroporosity character as described before. While for temperature effects, the data show that as the temperature rises, the percent of conversion also increases, which could be associated with the increasing of kinetic energy possessed by reactants. As shown in Figure $8(\mathrm{~b})$, the reaction at $80^{\circ} \mathrm{C}$ gave only 4-hydroxybenzoic acid conversion of $42 \%$, while an increase in reaction temperature up to $100^{\circ} \mathrm{C}$ increased the conversion to $65 \%$. A further increase in temperature to $120^{\circ} \mathrm{C}$ only slightly increased the conversion to $71 \%$.
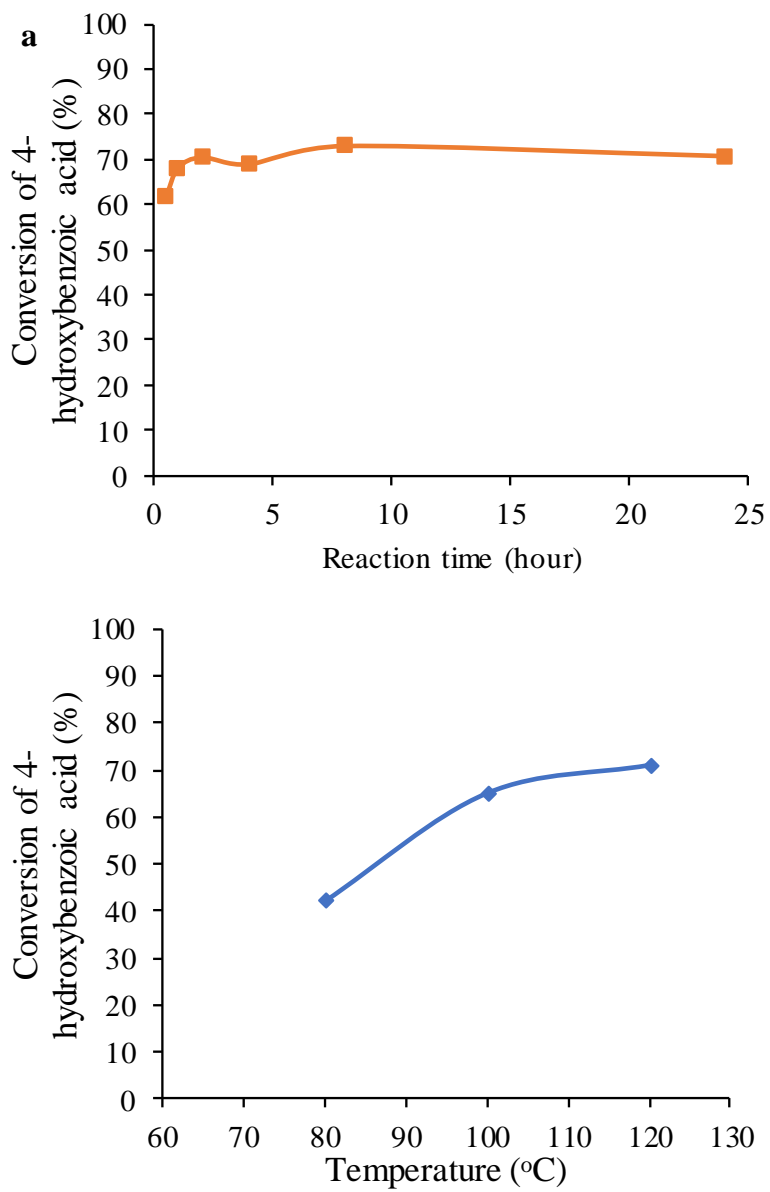

Figure 8. Effect of: (a) reaction time (over $\mathrm{AlCl}_{3} / \mathrm{SiO}_{2}$ catalyst) and (b) temperature to the 4-hydroxybenzoic acid conversion

\subsection{Antioxidant activity of the Product}

$\mathrm{IC}_{50}$ of the ester product was measured using the DPPH radical scavenging method, which gave the value of $65.07 \mathrm{ppm}$ as a preliminary result. This means that the ester could quench $50 \%$ of free radicals at a concentration of $65.07 \mathrm{ppm}$. Thus, the ester shows a good antioxidant activity since the $\mathrm{IC}_{50}$ value is below 200 ppm [26]. The IC50 value of the ester is much lower than that of 4-hydroxybenzoic acid, and six times larger than that of ascorbic acid, a commercially available and popular antioxidant (Table 3).

Table 3. Comparison of antioxidant activity of ester with 4-hydroxybenzoic acid and ascorbic acid. Radicals inhibition at 30 minutes

\begin{tabular}{cc|cc|cc}
\hline \multicolumn{2}{c|}{ Ester } & \multicolumn{2}{c|}{ 4-hydroxybenzoic acid } & \multicolumn{2}{c}{ Ascorbic acid } \\
\hline C (ppm) & \% inhibition & C (ppm) & \% inhibition & C (ppm) & \% inhibition \\
\hline 10 & 15.45 & 1000 & 0.48 & 1 & 3.09 \\
25 & 27.27 & 2000 & 2.55 & 10 & 54.74 \\
50 & 41.82 & 3000 & 6.85 & 20 & 82.21 \\
75 & 55.15 & 5000 & 12.58 & & \\
\hline IC50 & $65.07 \mathrm{ppm}$ & \multicolumn{2}{|c|}{$17741.33 \mathrm{ppm}$} & \multicolumn{2}{c}{$11.14 \mathrm{ppm}$} \\
\hline
\end{tabular}

\section{Conclusion}

Silica extracted from kaolin could be utilized as solid support for the immobilization of both Bronsted and Lewis Acid, and further used as a heterogeneous catalyst in esterification reaction of 4-hydroxybenzoic acid with sucrose. The high selectivity of the catalysts toward the formation of monoester might be caused primarily by the structure of the catalyst with its mesopore structure. The esters show good antioxidant activity with the inhibitor concentration $\left(\mathrm{IC}_{50}\right)$ of $65.07 \mathrm{ppm}$.

\section{References}

[1] Fuangfa Unob, Benjawan Wongsiri, Nuchnicha Phaeon, Mahitti Puanngam and Juwadee Shiowatana, Reuse of waste silica as adsorbent for metal removal by iron oxide modification, Journal of Hazardous Materials, 142, 1, (2007), 455-462 https://doi.org/10.1016/j.jhazmat.2006.08.049

[2] Benjamin Curdts, Christian Pflitsch, Christoph Pasel, Martin Helmich, Dieter Bathen and Burak Atakan, Novel silica-based adsorbents with activated carbon structure, Microporous and Mesoporous Materials, 210, (2015), 202-205 https://doi.org/10.1016/j.micromeso.2015.02.007

[3] Choiril Azmiyawati, Kajian Kinetika Adsorpsi Mg(II) pada Silika Gel Termodifikasi Gugus Sulfonat, Jurnal Kimia Sains dan Aplikasi, 9, 2, (2006), 35-39 https://doi.org/10.14710/jksa.9.2.35-39

[4] Yasuhiro Kamitori, Masaru Hojo, Ryoichi Masuda, Tatsuo Izumi and Shuichi Tsukamoto, Silica gel as an effective catalyst for the alkylation of phenols and some heterocyclic aromatic compounds, The Journal of Organic Chemistry, 49, 22, (1984), 4161-4165 https://doi.org/10.1021/jo00196a012

[5] Kidon Nam, Seongyop Lim, Sang-Kyung Kim, Seong-Ho Yoon and Doo-Hwan Jung, Application of silica as a catalyst support at high concentrations of methanol for direct methanol fuel cells, International Journal of Hydrogen Energy, 37, 5, (2012), 4619-4626 https://doi.org/10.1016/j.ijhydene.2011.05.068

[6] Rafael Huirache-Acuña, Rufino Nava, Carmen L. Peza-Ledesma, Javier Lara-Romero, Gabriel Alonso-Núez, Barbara Pawelec and Eric M. RiveraMuñoz, SBA-15 Mesoporous Silica as Catalytic Support for Hydrodesulfurization CatalystsReview, Materials, 6, 9, (2013), 4139-4167 https://doi.org/10.3390/ma6094139

[7] Arne Thomas, Frederic Goettmann and Markus Antonietti, Hard Templates for Soft Materials: Creating Nanostructured Organic Materials, 
Chemistry of Materials, 20, 3, (2008), 738-755 https://doi.org/10.1021/cm702126j

[8] HaYeon Lee and Cafer T. Yavuz, Increasing mesoporosity by a silica hard template in a covalent organic polymer for enhanced amine loading and CO2 capture capacity, Microporous and Mesoporous Materials, 229, (2016), 44-50

https://doi.org/10.1016/j.micromeso.2016.04.019

[9] Ahmad Bitar, Nasir M. Ahmad, Hatem Fessi and Abdelhamid Elaissari, Silica-based nanoparticles for biomedical applications, Drug Discovery Today, 17, 19, (2012), 1147-1154 https://doi.org/10.1016/j.drudis.2012.06.014

[10] Naiara I. Vazquez, Zoilo Gonzalez, Begoña Ferrari and Yolanda Castro, Synthesis of mesoporous silica nanoparticles by sol-gel as nanocontainer for future drug delivery applications, Boletín de la Sociedad Española de Cerámica y Vidrio, 56, 3, (2017), 139-145 https://doi.org/10.1016/j.bsecv.2017.03.002

[11] Ridla Bakri, Tresye Utari and Indra Puspita Sari, Kaolin sebagai sumber $\mathrm{SiO}_{2}$ untuk pembuatan katalis $\mathrm{Ni} / \mathrm{SiO}_{2}$ : karakterisasi dan uji katalis pada hidrogenasi benzena menjadi sikloheksana, Makara Journal of Science, 12, 1, (2010), 37-43 https://doi.org/10.7454/mss.v12i1.304

[12] Usama Zulfiqar, Tayyab Subhani and S. Wilayat Husain, Synthesis and characterization of silica nanoparticles from clay, Journal of Asian Ceramic Societies, 4, 1, (2016), 91-96 https://doi.org/10.1016/j.jascer.2015.12.001

[13] Franz X. Gingele, Patrick De Deckker and ClausDieter Hillenbrand, Clay mineral distribution in surface sediments between Indonesia and NW Australia - source and transport by ocean currents, Marine Geology, 179, 3, (2001), 135-146 https://doi.org/10.1016/S0025-3227(01)00194-3

[14]Asit K. Chakraborti, Bavneet Singh, Sunay V. Chankeshwara and Alpesh R. Patel, Protic Acid Immobilized on Solid Support as an Extremely Efficient Recyclable Catalyst System for a Direct and Atom Economical Esterification of Carboxylic Acids with Alcohols, The Journal of Organic Chemistry, 74, 16, (2009), 5967-5974

https://doi.org/10.1021/j0900614s

[15] Wilmar Osorio-Viana, Miguel Duque-Bernal, Javier Fontalvo, Izabela Dobrosz-Gómez and Miguel Ángel Gómez-García, Kinetic study on the catalytic esterification of acetic acid with isoamyl alcohol over Amberlite IR-120, Chemical Engineering Science, 101, (2013), 755-763 https://doi.org/10.1016/j.ces.2013.07.009

[16] Pepijn Prinsen, Rafael Luque and Camino GonzálezArellano, Zeolite catalyzed palmitic acid esterification, Microporous and Mesoporous Materials, 262, (2018), 133-139

https://doi.org/10.1016/j.micromeso.2017.11.029

[17] Leandro Zatta, Luiz Pereira Ramos and Fernando Wypych, Acid-activated montmorillonites as heterogeneous catalysts for the esterification of lauric acid acid with methanol, Applied Clay Science, 80-81, (2013), 236-244 https://doi.org/10.1016/j.clay.2013.04.009

[18] Enas A. Almadani, Farah W. Harun, Salina M. Radzi and Syamsul K. Muhamad, $\mathrm{Cu}^{2+}$ Montmorillonite K10 Clay Catalyst as a Green Catalyst for Production of
Stearic Acid Methyl Ester: Optimization Using Response Surface Methodology (RSM), Bulletin of Chemical Reaction Engineering, 13, 1, (2018), 187-195 https://doi.org/10.9767/bcrec.13.1.1397.187-195

[19]Mehejabeen Kotwal, Anuj Kumar and Srinivas Darbha, Three-dimensional, mesoporous titanosilicates as catalysts for producing biodiesel and biolubricants, Journal of Molecular Catalysis A: Chemical, 377, (2013), 65-73

https://doi.org/10.1016/j.molcata.2013.04.029

[20]Roberta Gomes Prado, Maria Lucia Bianchi, Estella Gaspar da Mota, Sarah Silva Brum, João Henrique Lopes and Márcio José da Silva, $\mathrm{H}_{3} \mathrm{PMO}_{12} \mathrm{O}_{40}$ /Agroindustry Waste Activated CarbonCatalyzed Esterification of Lauric Acid with Methanol: A Renewable Catalytic Support, Waste and Biomass Valorization, 9, 4, (2018), 669-679 https://doi.org/10.1007/s12649-017-0012-0

[21] Emma M. Björk, María P. Militello, Luciano H. Tamborini, Rusbel Coneo Rodriguez, Gabriel A. Planes, Diego F. Acevedo, M. Sergio Moreno, Magnus Odén and Cesar A. Barbero, Mesoporous silica and carbon based catalysts for esterification and biodiesel fabrication-The effect of matrix surface composition and porosity, Applied Catalysis A General, 533, (2017), 49-58

https://doi.org/10.1016/j.apcata.2017.01.007

[22]Reza Farhoosh, Saeed Johnny, Maryam Asnaashari, Najme Molaahmadibahraseman and Ali Sharif, Structure-antioxidant activity relationships of 0 hydroxyl, o-methoxy, and alkyl ester derivatives of p-hydroxybenzoic acid, Food Chemistry, 194, (2016), 128-134 https://doi.org/10.1016/j.foodchem.2015.08.003

[23] Sun-Yup Shim, Ye E. Lee, Hwa Y. Song and Mina Lee, p-Hydroxybenzoic Acid $\beta$-d-Glucosyl Ester and Cimidahurinine with Antimelanogenesis and Antioxidant Effects from Pyracantha angustifolia via Bioactivity-Guided Fractionation, Antioxidants, 9, 3, (2020), https://doi.org/10.3390/antiox9030258

[24]Coral Barbas, Javier Rupérez, Andre Dams and Ronald E. Majors, Separation of paraben preservatives by reversed-phase HPLC application in foods, beverages, cosmetics, in, Agilent Technologies, Amstelveen, The Netherlands, 2005, pp. 1-4

[25]Philip Molyneux, The use of the stable free radical diphenylpicrylhydrazyl (DPPH) for estimating antioxidant activity, Songklanakarin Journal of Science and Technology (SJST), 26, 2, (2004), 211-219

[26]Pratiwi, Dewi Puspa and Mindarti Harapini, Peroxide value and DPPH (diphenyl picril hydrazil hydrate) free radical scavenger activity of Knema laurina methanol extract, Indonesian Journal of Pharmacy, 17, 1, (2006), 32-36

http://dx.doi.org/10.14499/indonesianjpharmoissopp32-36

[27]M. H. Gaber, N. A. Abd el Halim and W. A. Khalil, Antioxidant activity of ascorbic acid against peroxidation of phosphatidylcholine liposomes exposed to gamma radiation: a synergistic interaction?, Romanian Journal of Biophysics, 12, 3-4, (2002), 103-115

[28]Horacio E. Bergna, Colloid Chemistry of Silica, in: The Colloid Chemistry of Silica, American Chemical Society, 1994, pp. 1-47 https://doi.org/10.1021/ba-1994-0234.choo1 
[29]Helmut Günzler, Hans Ulrich Gremlich and Herbert Heise, IR Spectroscopy: An Introduction, John Wiley \& Sons, Limited, 2002

[30]Fu Yang and Jingjing Tang, Catalytic Upgrading of Renewable Levulinic Acid to Levulinate Esters Using Perchloric Acid Decorated Nanoporous Silica Gels, ChemistrySelect, 4, 4, (2019), 1403-1409

https://doi.org/10.1002/slct.201803608 